SLAC-WP-078

November 2007

\title{
Coreless Concept for High Gradient Induction Cell
}

\author{
Anatoly Krasnykh
}




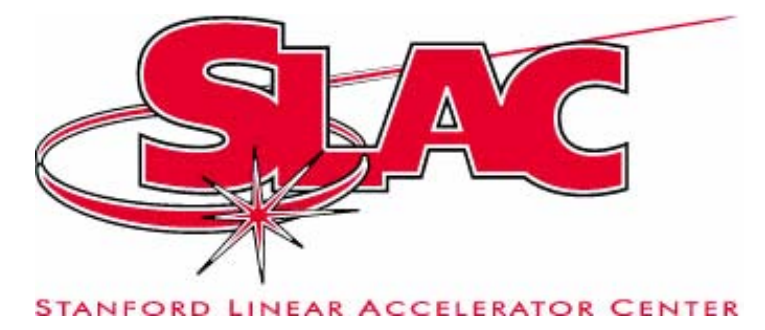

\title{
Coreless Concept
}

for High Gradient Induction Cell

\author{
Anatoly Krasnykh \\ (Klystron Dept. of SLAC) \\ and \\ Alexei Kardo-Sysoev \\ (Ioffe Physical Technical Institution, \\ St. Petersburg, Russia)
}




\section{Outline}

- Introduction. Items for Consideration

- Accelerating Gradient in Induction Linacs

- Analyze Ways How to Increase Gradient

- High Gradient (HG) Cell based on Solid State Approaches

- SLIM ${ }^{\odot}:$ SLAC Induction Module (or Method)

- Conclusion 


\section{Items for Consideration}

- Why accelerating gradient of existing induction linacs is weaker than classical rflinacs? Can the induction linacs possesses the accelerating gradient similar to rf-linac gradients?

- A typical pulse width for an induction system is several tenth of nanoseconds (let's say 30-100 nsec). Can the induction system deals with 10 times shorter pulses?

- Presentation is based on our R\&D results 


\section{What is a typical accelerating gradient of induction linacs?}

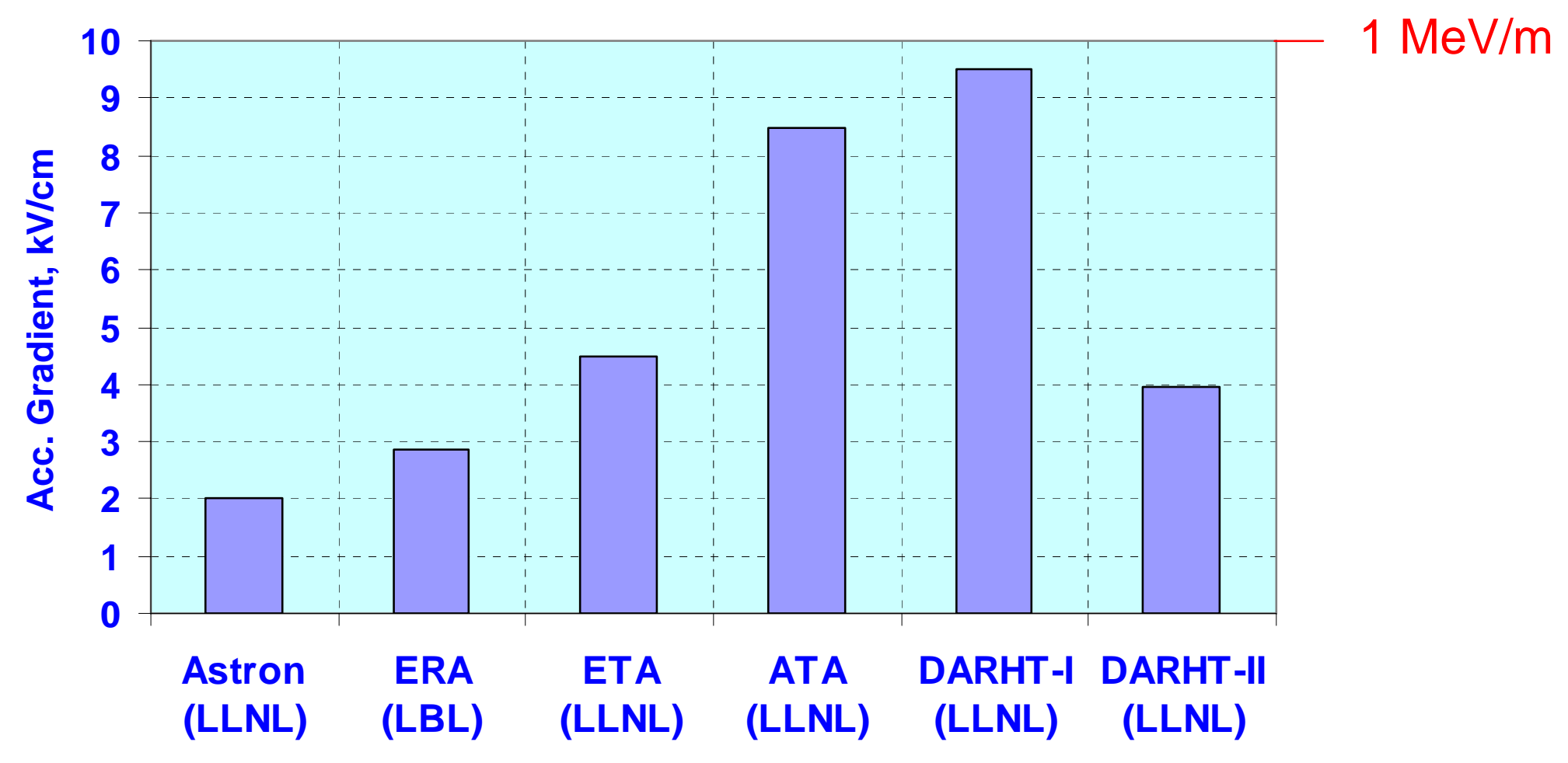

The machines were build in the period 1963-2003 (i.e. the 40 years progress)

Machines in other countries (France, Russia, China, etc.) have similar accelerating gradient 


\section{Two Induction Approaches}

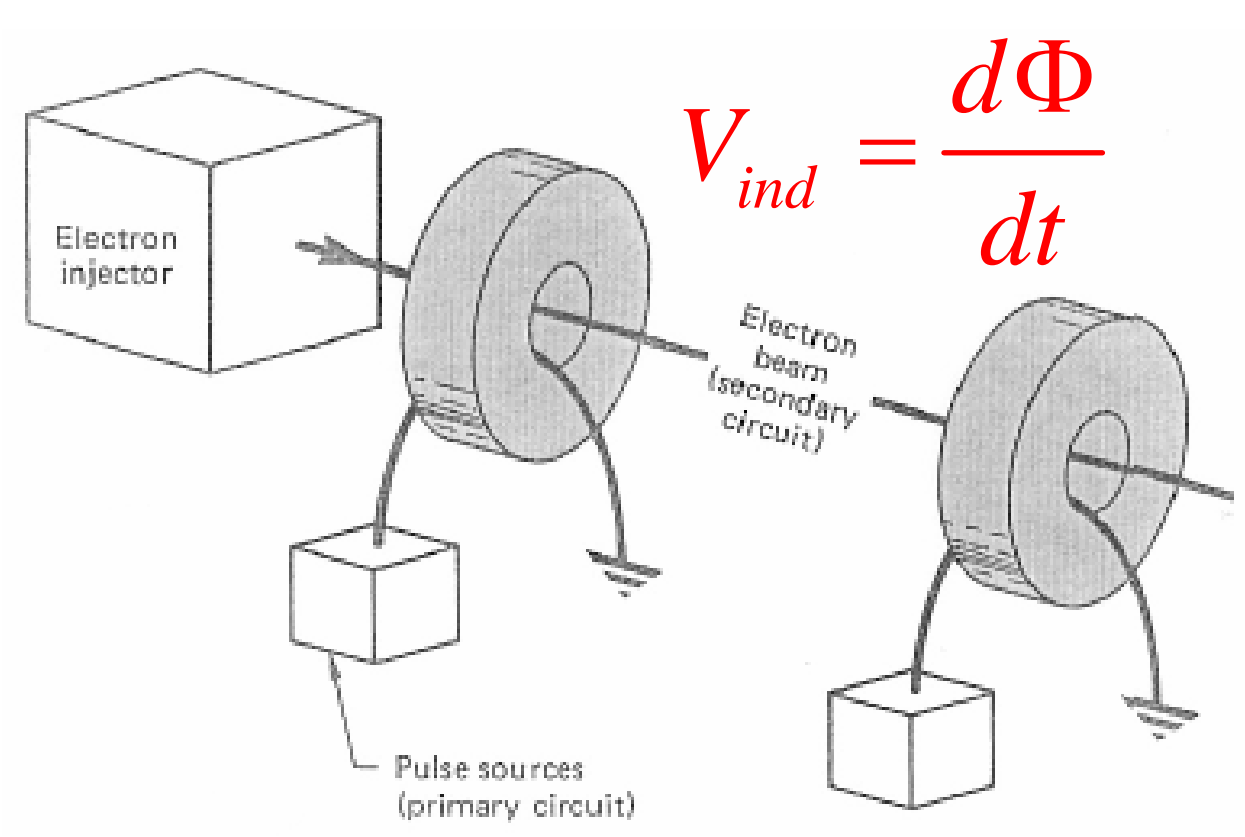

One Cell of Induction System

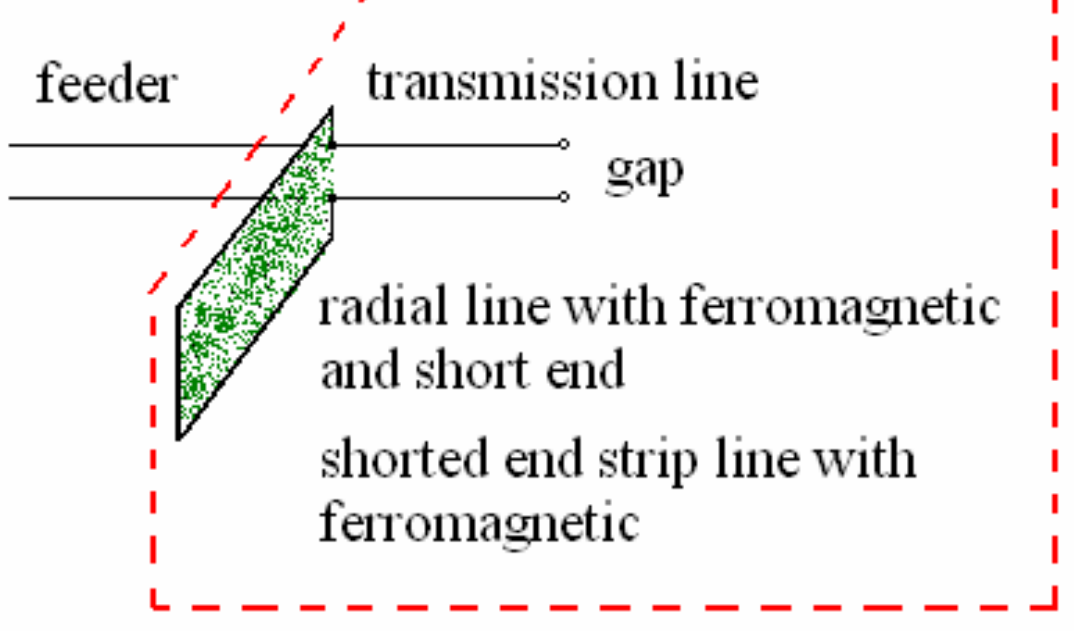

The transmission line approach helps to understand the role of components of individual cells (there is a contrasting view of the energy transfer from the source to the beam)

A classical approach of a working principle for the induction system does not allow us to make a leap forward on the gradient improvement 


\section{Heart of Coreless Approach}

- Sub nanosecond mode operation

- Induction system is an array of the solid state cells with a tiny section length (in $\mathrm{mm}$ range)

- High accelerating gradient is formed by a transition process in induction system

- Solid state switches are integrated into cells

- Normal switch condition is close. Energy is storied in a magnetic form

- Switches are controlled by a form of the pumping induction system current 


\section{Results of Pioneering R\&D for the Solid State Coreless HG Induction Linac (cont.)}
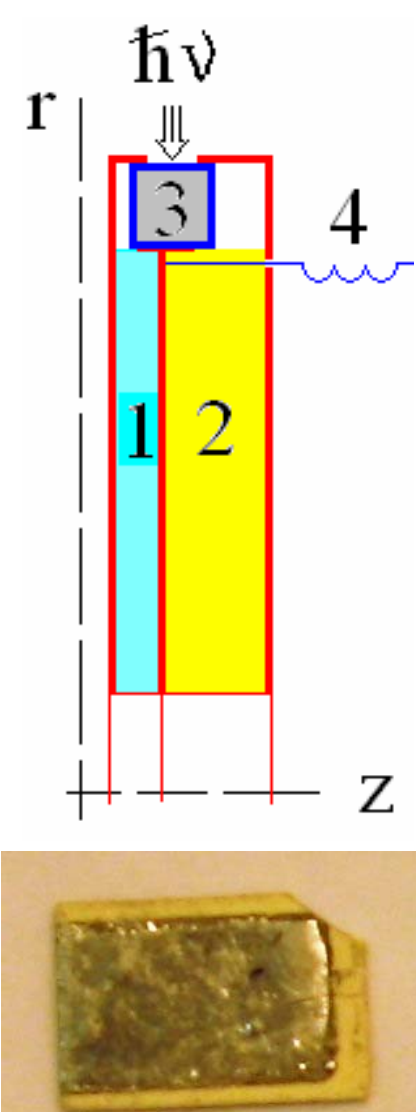

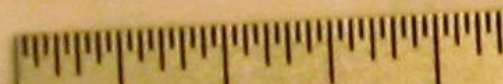
$\frac{1 / 2 m m}{m m} 10 \quad 20$
10 nsec Sicond $^{\odot}$ stripline

(Slide-rule is for a scaling)

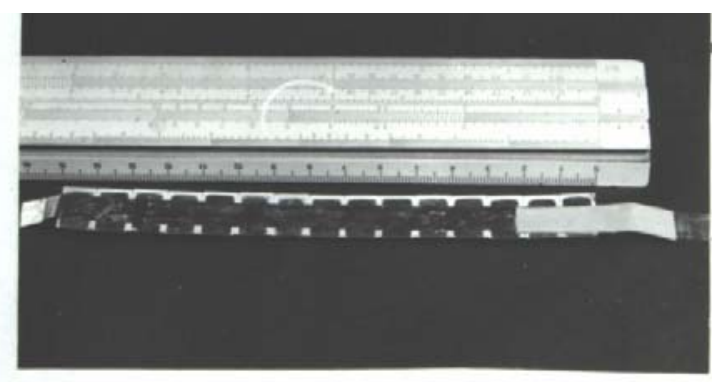

Pис. I9. Полостовая линия из конденсаторов

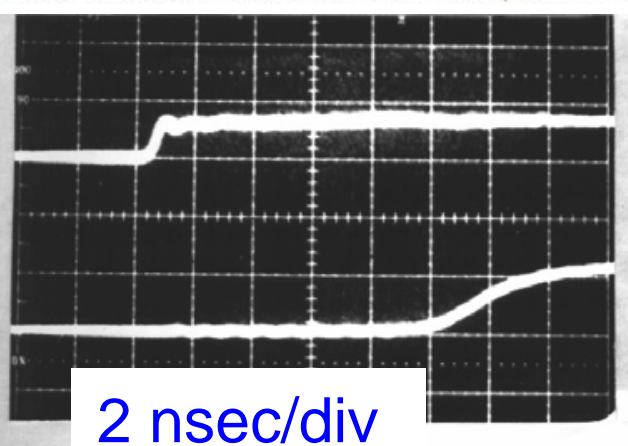

Рис. 20. Временная задержка по линии. Верхний луч - импульс на входе;<smiles>C1CC2CCC1C2</smiles>

Solid State Switch driven by Pulsed Photon Flux in HG DWA Concept The cell thickness is $\sim 1.6 \mathrm{~mm}$.

Cells with a tiny section length are a prototype for the SLIM ${ }^{\odot}$ 


\section{Results of Pioneering R\&D for the Solid State Coreless HG Induction Linac (cont.)}

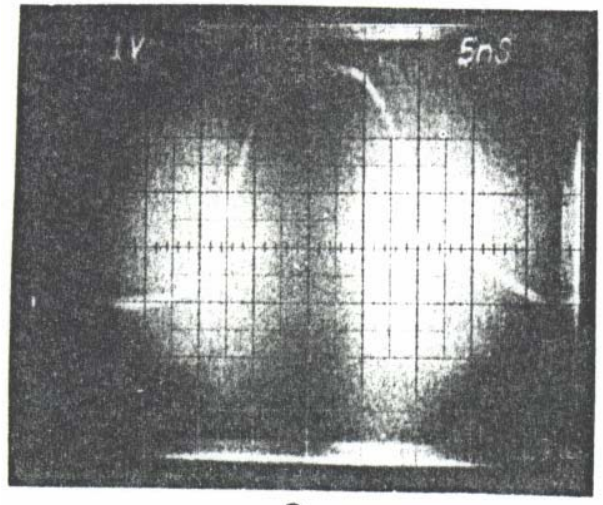

$E \simeq 10 \frac{\mathrm{kB}}{\mathrm{cm}}$

))

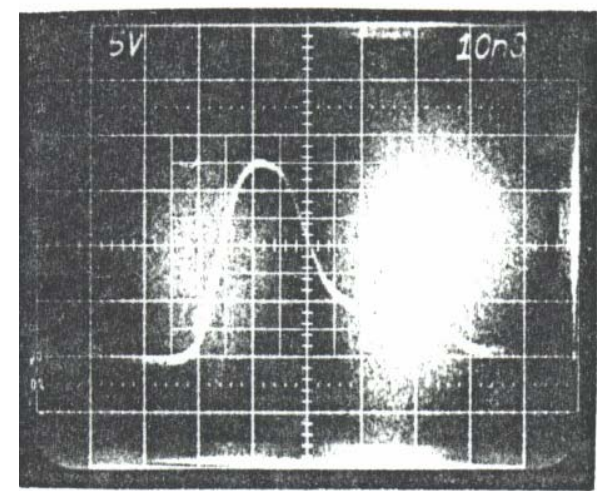

$E \simeq 50 \frac{\mathrm{NB}}{\mathrm{CM}}$

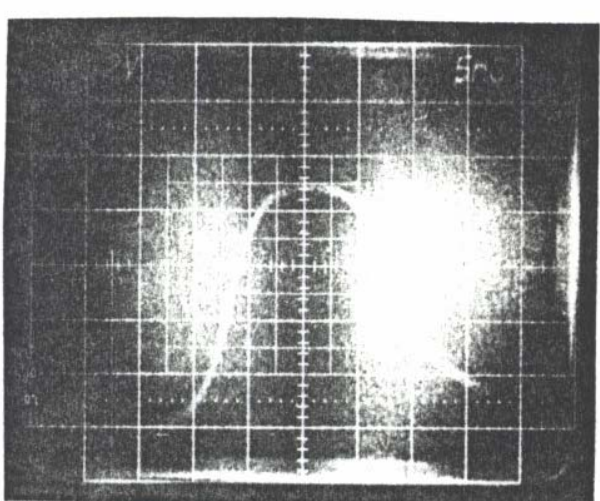

$$
\left.E \simeq 20 \frac{k B}{c m} \quad b\right)
$$

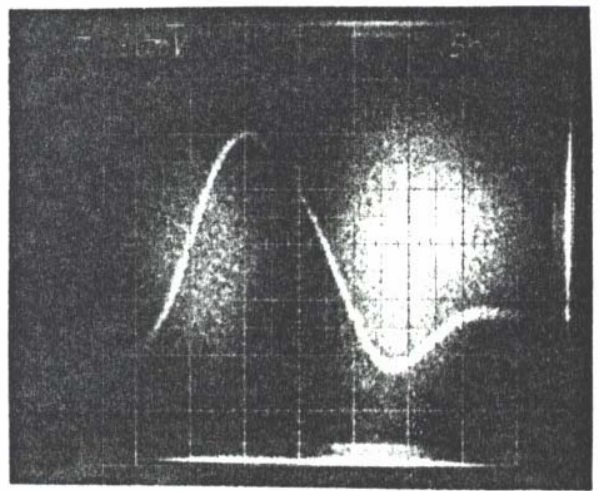

g)
Cell Impedance is $\sim 2.5 \mathrm{Ohm}$ R_load 3 Ohm

$\mathrm{Nd}$ :YAG 1064nm Laser, Wph=20 mJ, $t_{p}=10 \mathrm{nsec}$

Output Amplitude vs. Photon Energy

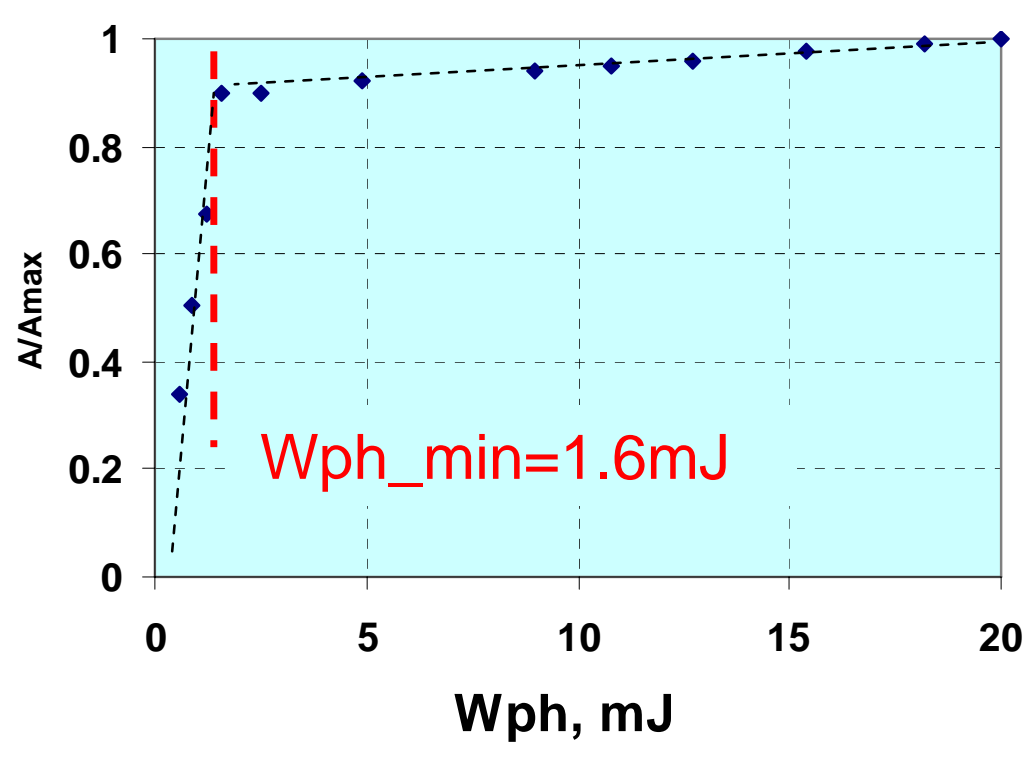

$5 \mathrm{MeV} / \mathrm{m}$ was shown, see Proc. on Collective Methods of Acceleration, Dubna, 1982 


\section{A DW Cell with a Ferromagnetic Switch}
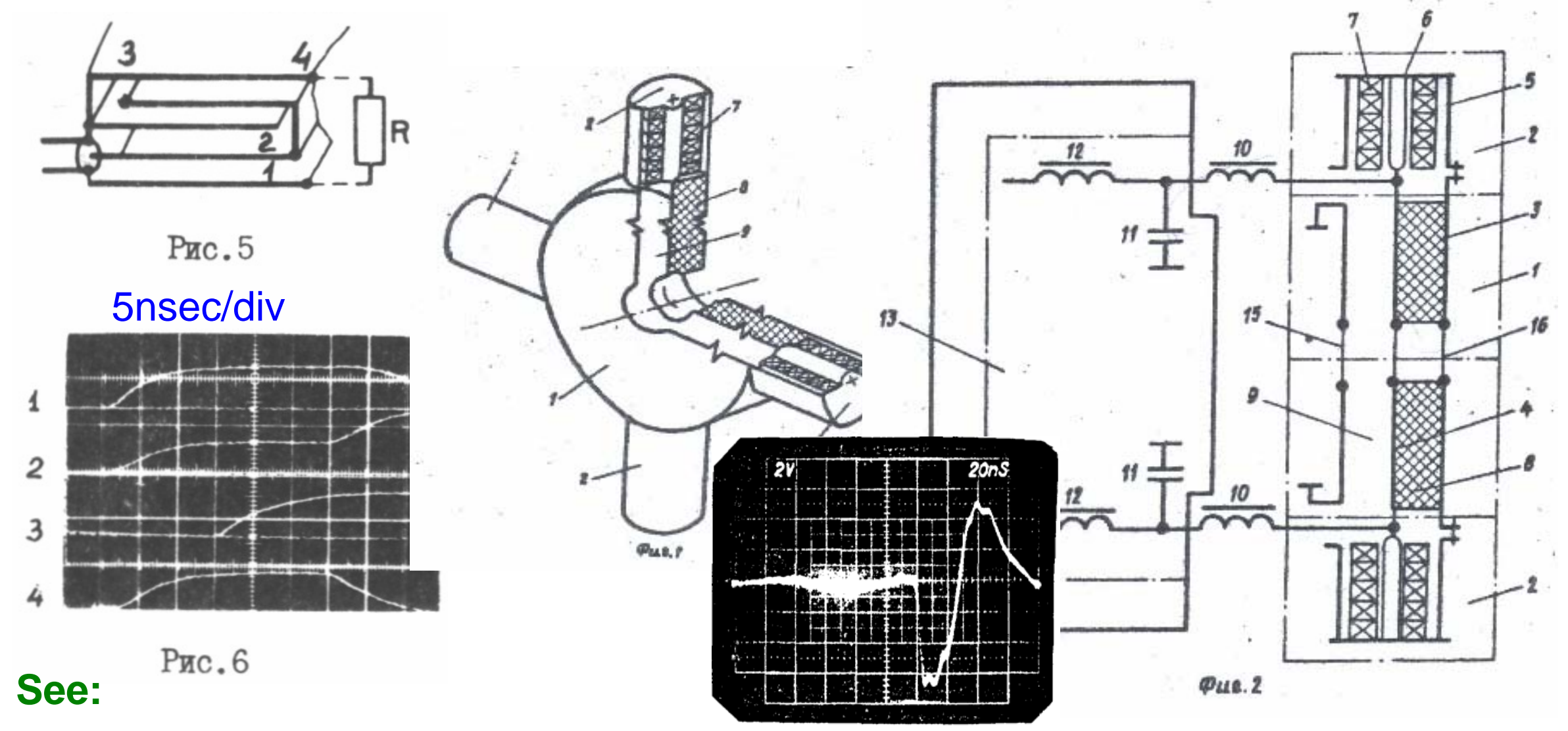

See: Рис. 6

- Proc. on Collective Methods of Acceleration, Dubna, 1982

- SU patent \#1263189, H 05h 9/00, filed January 1985

The rebirth of DW cell was in USA by B. Carder in 1997, patent \# 5,757,146

see also G. Caporaso application US2007/0145916 filed Oct. 24, 2006 


\section{DW Cell driven by the DSRDs}

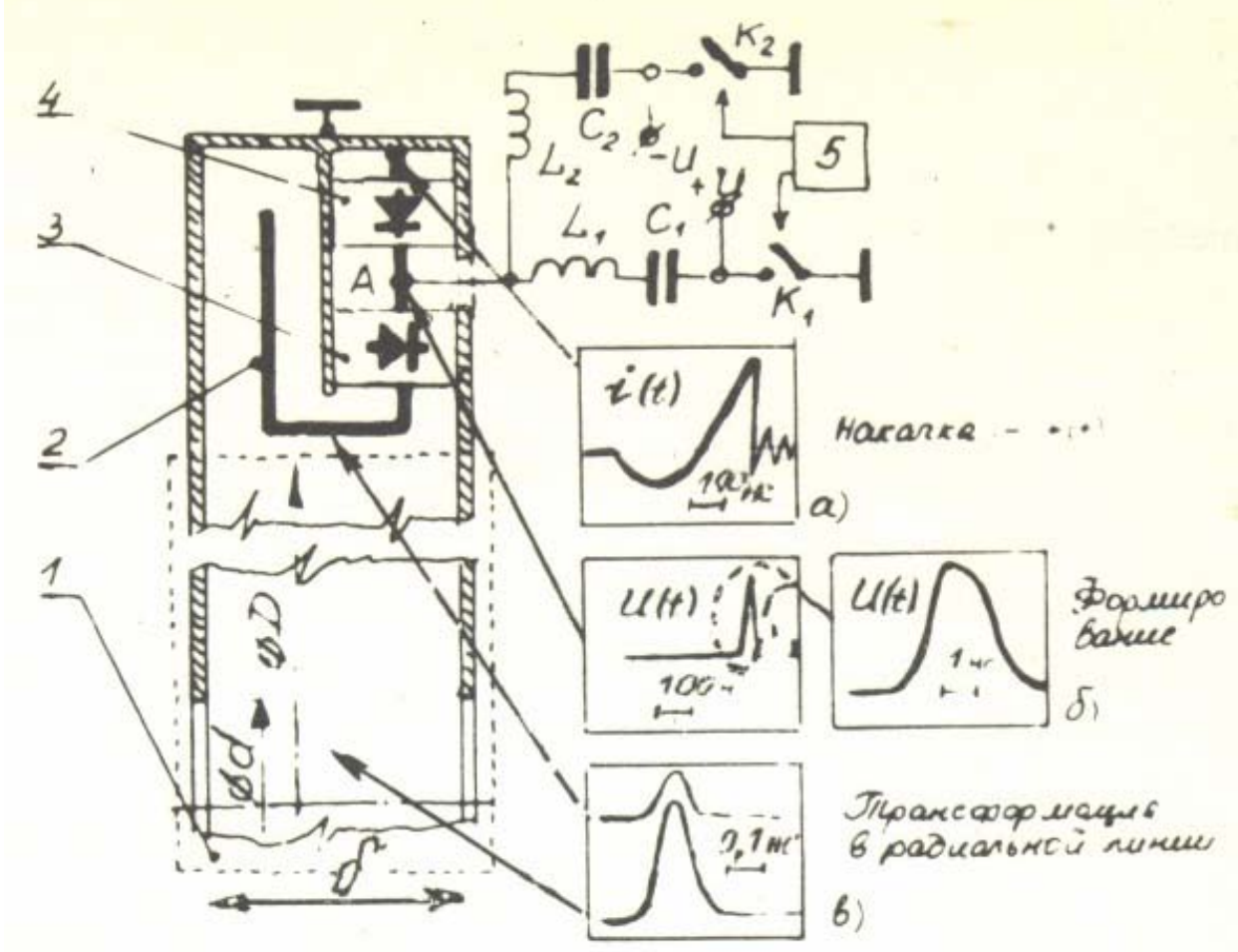

Puc.I.

Pulse transformation in the radial line that is imposed in the inductor
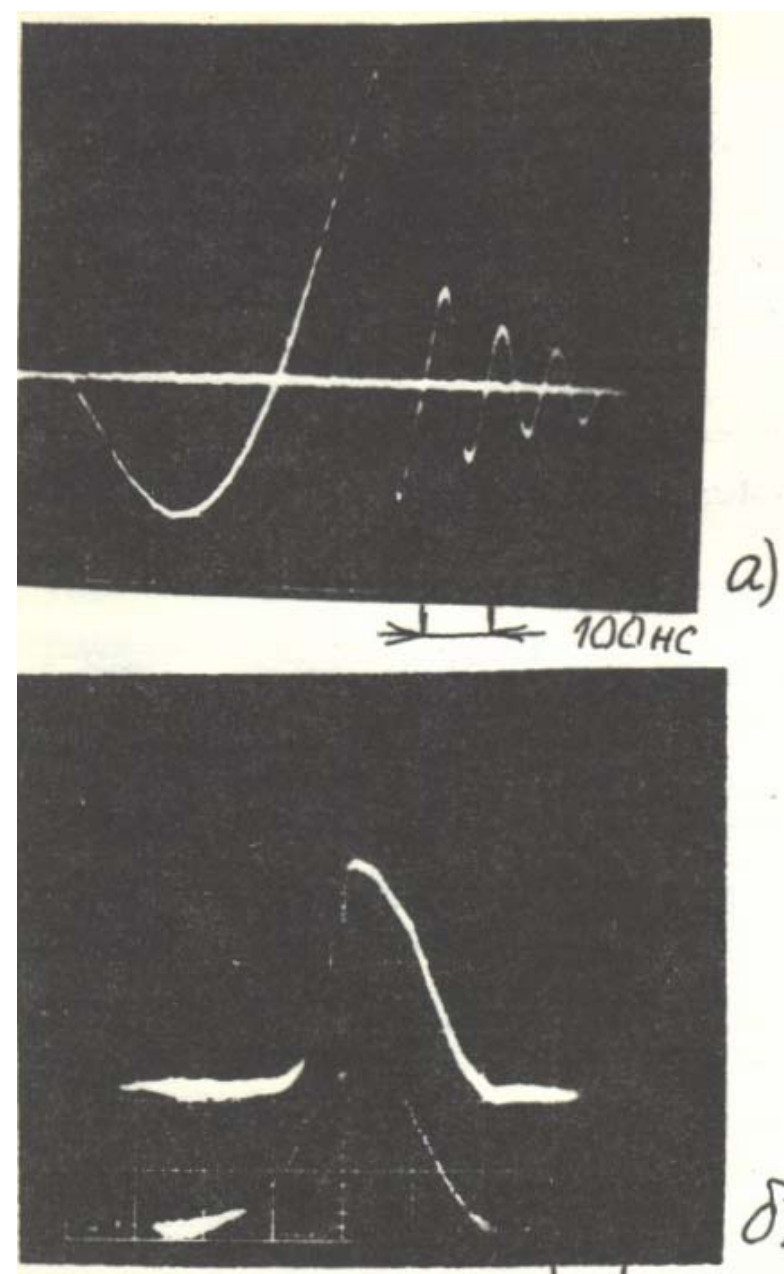

б)

Puc.2. $>20 \mathrm{HC}$ see 11nd All Union Conference on Charged Particle Accelerators, Dubna, 1988 


\section{Transmission Line with a Close-Open-Close Switch}

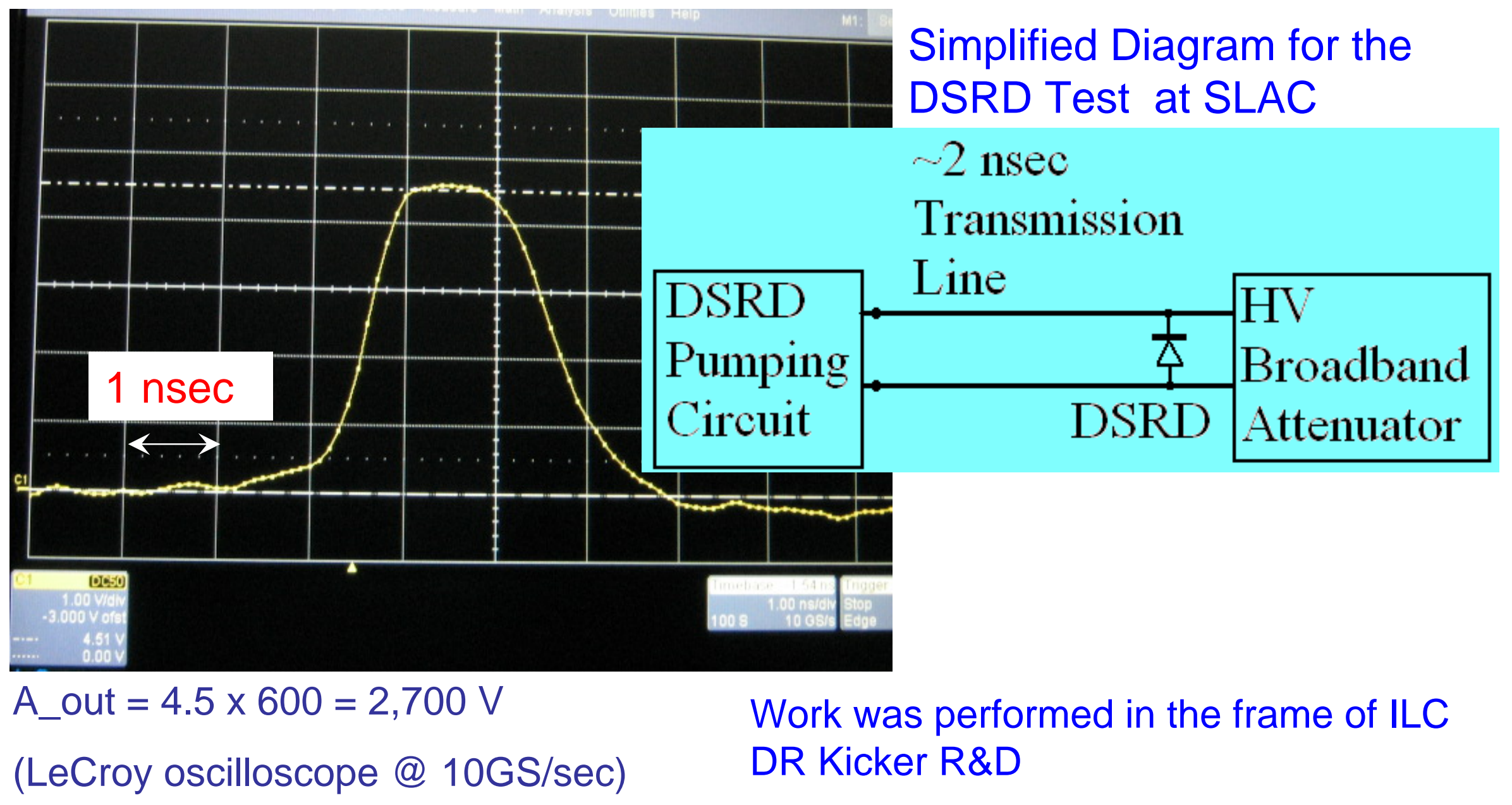

See presentation on ILCDR06 (Sept. 2006, Cornell University, SLAC-WP-077) 


\section{A Progress in the HG Vacuum-to-Media Interface Development (results from the LLNL team)}
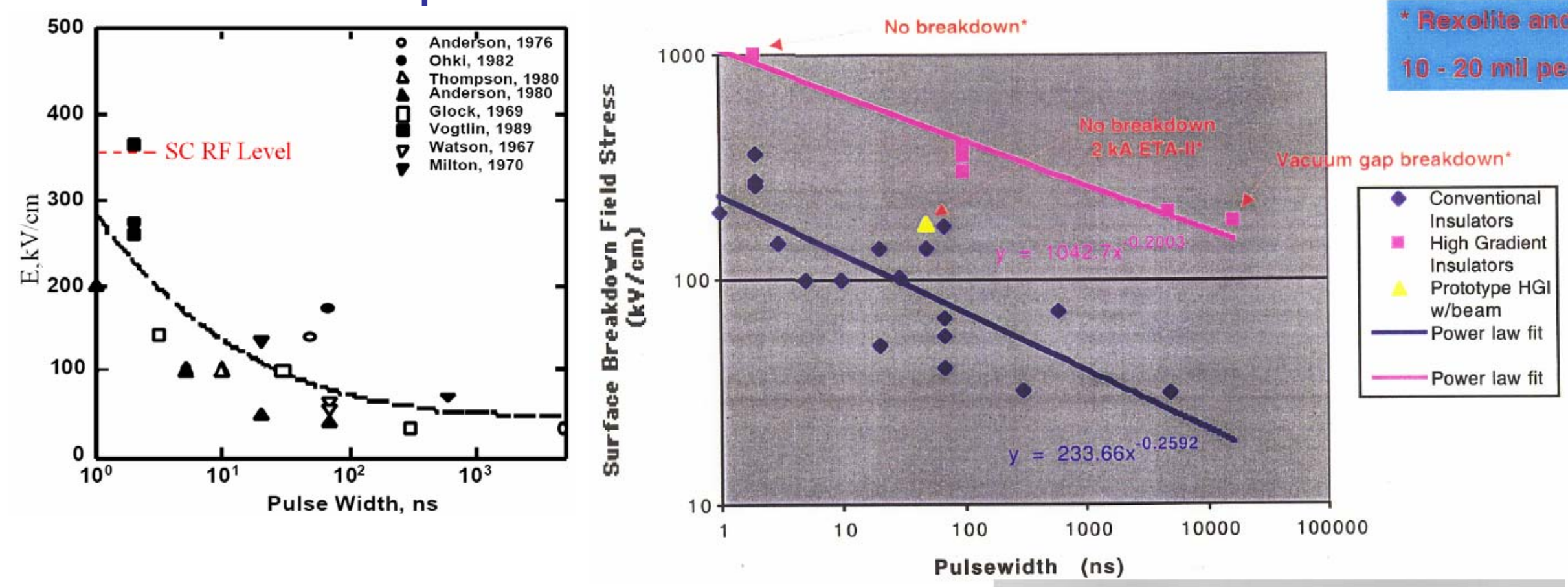

Pulsed surface breakdown electric field as a function of pulse width for single substrate, straight wall insulators (see G. Caporaso et al, UCRL-JC-127274)

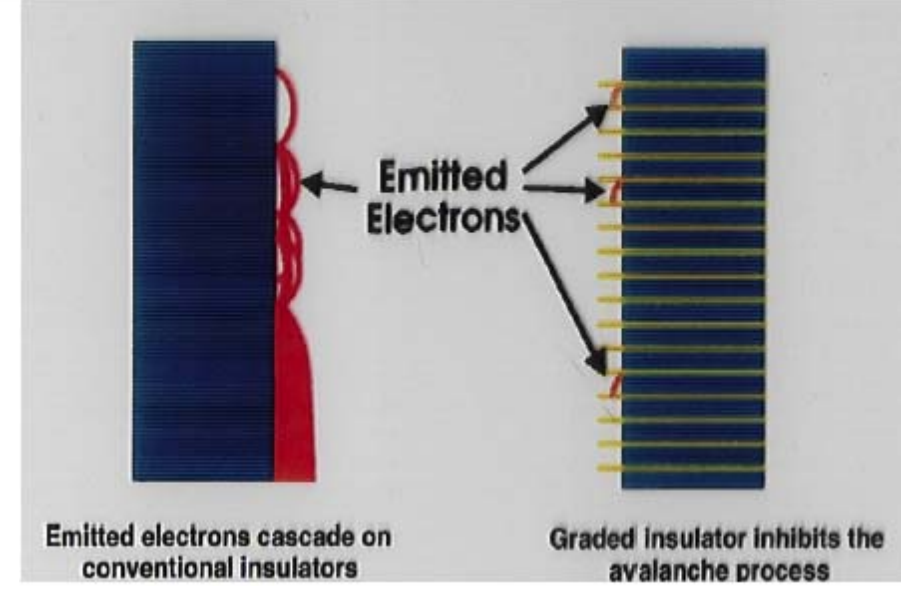




\section{SLIM $^{\odot}$ : Feasible Topology for HG Coreless DW Cell}
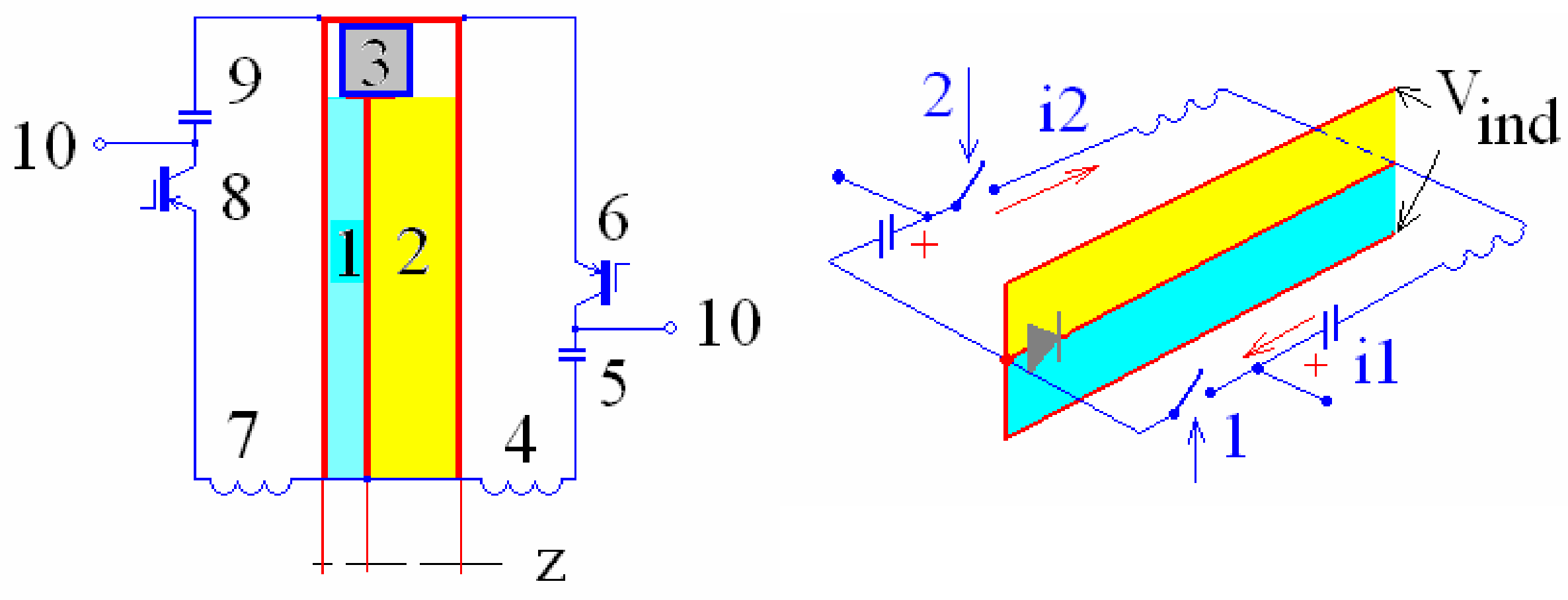

Thin in z direction Cell with a DSRD Mode Operation and the Open IR Ends 


\section{SLIM $^{\odot}$ : Feasible Topology for HG Solid}

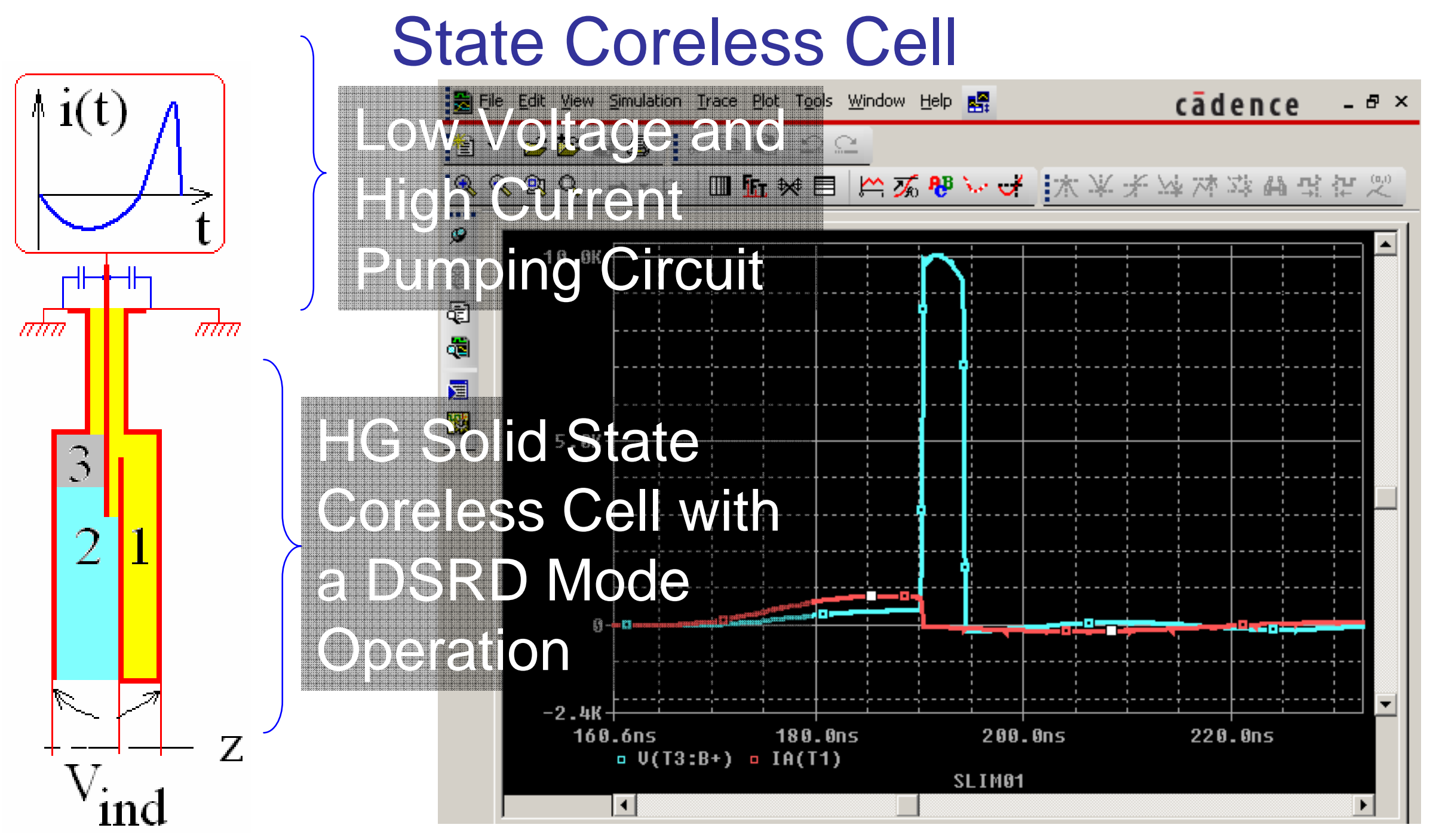

Tiny Cell with the Open and Short IR End 


\section{SLIM ${ }^{\odot}$ : Feasible Topology for HG Coreless Induction Module}

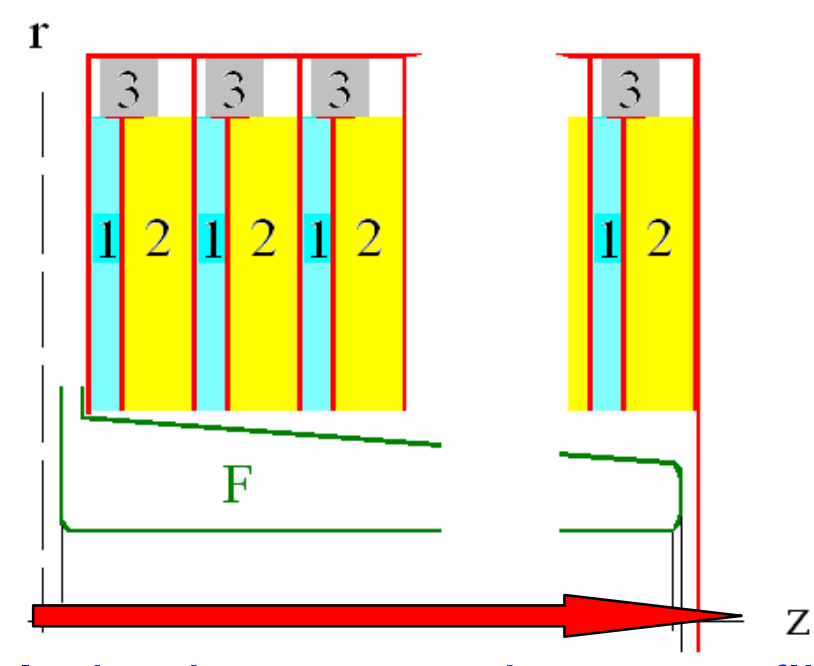

Induction system is not conflict with the SC Foc. System (no ferromagnetic cores)

High efficiency suitable to operate with the high rep. rate (the $p+$ synchrotron's cavity)
The induction system is a storage energy element

The storage energy is practically delivered to the beam during interval of several nsec, i.e. the concept has high efficiency

The nsec mode operation may run with a high gradient that is comparable with the rf-linac gradient ( $30 \mathrm{MeV} / \mathrm{m} @ 5$ nsec FWHM)

DSRD solid state switches are controlled precisely (jitter $-30 \mathrm{psec}$ ) by the electrical trigger

High rep. rate (up to several $\mathrm{MHz}$ ) is possible

The full size proposed SLIM ${ }^{\odot}$ did not implement. There is a need for system technology design and tests. 


\section{Some Important Features for the SLIM ${ }^{\odot}$}
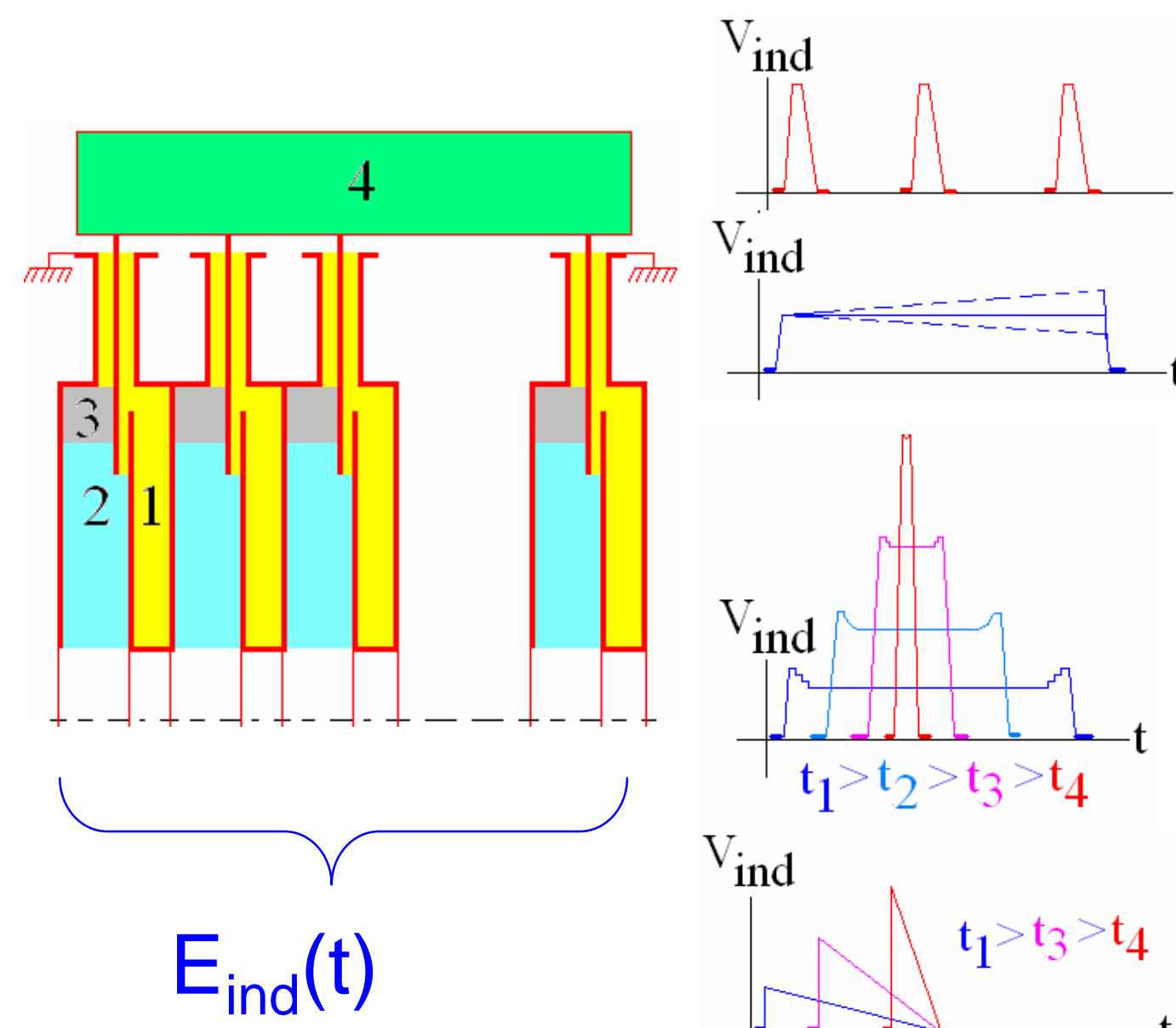

HG Mode Operation with High Rep. Rate (synchronization all DSRDs as one switch)

Possible Fast Control of the Spatial E(z,t) Distribution along Induction System

$\mathrm{V}_{\text {ind }}$

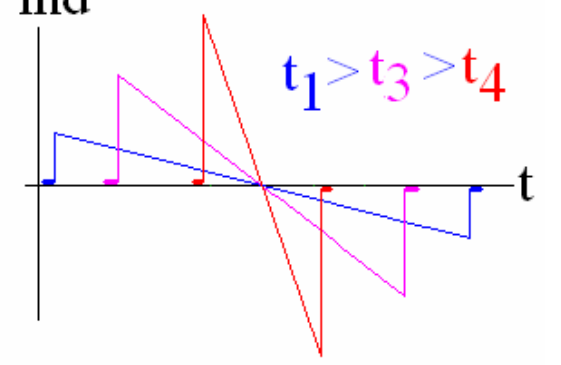

Acc. Structure with $\mathrm{Q}=1$ (Broadband Impedance) and Alternating Gradient in the $\mathrm{MHz}$ range is feasible 


\section{Other Programs Based on Induction Linac Topology}

Summary of applications for induction accelerators

\begin{tabular}{|c|c|c|c|c|c|}
\hline $\begin{array}{l}\text { Application/ } \\
\text { Architechture }\end{array}$ & Voltage & $\begin{array}{l}\text { Beam } \\
\text { Current }\end{array}$ & $\begin{array}{l}\text { Pulse } \\
\text { length }\end{array}$ & $\begin{array}{l}\text { Rep. } \\
\text { rate }\end{array}$ & Issues/comments \\
\hline $\begin{array}{l}\text { Hadron colliderl } \\
\mathrm{p}^{+} \text {ind. synchrotron }\end{array}$ & $\begin{array}{l}31 \mathrm{TeV} ; 3 \\
\text { MeV/turn }\end{array}$ & $25 \mathrm{~A}$ & $500 \mathrm{~ns}$ & $\begin{array}{l}100 \mathrm{kHz} \\
\mathrm{CW}\end{array}$ & $\begin{array}{l}\text { feasibility study going } \\
\text { on; require upgrade of } \\
\text { most existing detector } \\
\text { components for } \\
\text { higher L. competitor: } \\
\text { low harmonic rf }\end{array}$ \\
\hline $\begin{array}{l}\text { RK Two Beam Acc } \\
\text { for Linear } \\
\text { Colliders/e- ind. } \\
\text { linac }\end{array}$ & $\begin{array}{l}10 \mathrm{MeV}, \\
0.3 \\
\mathrm{MeV} / \mathrm{m}\end{array}$ & $1 \mathrm{kA}$ & $\begin{array}{l}50- \\
200 \mathrm{~ns}\end{array}$ & $180 \mathrm{~Hz}$ & $\begin{array}{l}\text { fundamental aspect } \\
\text { has been } \\
\text { demonstrated; no } \\
\text { current funding }\end{array}$ \\
\hline $\begin{array}{l}\text { Neutrino factory; } \mu \text { - } \\
\text { collider } / \mu \text {-ind. } \\
\text { linac }\end{array}$ & $\begin{array}{l}200 \mathrm{MeV} \\
2 \mathrm{MeV} / \mathrm{m}\end{array}$ & & $100 \mathrm{~ns}$ & $\begin{array}{l}4 \text { pulse @ } \\
3 \mathrm{MHz} ; 15 \\
\mathrm{~Hz} \text { avg. }\end{array}$ & $\begin{array}{l}\text { feasibility study going } \\
\text { on; competition with } \\
\text { low freq rf device; } \\
\text { can survive rad. env.; }\end{array}$ \\
\hline $\begin{array}{l}\text { Heavy lon Fusion/ } \\
\mathrm{HI}^{+} \text {ind. linac }\end{array}$ & $\begin{array}{l}4 \mathrm{GeV} \\
1.5 \\
\mathrm{MeV} / \mathrm{m}\end{array}$ & $\begin{array}{l}0.2-10 \\
k A\end{array}$ & $\begin{array}{l}20 \mu \mathrm{s}- \\
10 \mathrm{~ns}\end{array}$ & $\sim 6 \mathrm{~Hz}$ & $\begin{array}{l}\text { Significant program } \\
\text { ongoing }\end{array}$ \\
\hline
\end{tabular}

\section{Summary of applications for induction accel's-cont'd}

\begin{tabular}{|l|l|l|l|l|l|}
\hline $\begin{array}{l}\text { Application/ } \\
\text { Architechture }\end{array}$ & Voltage & $\begin{array}{l}\text { Beam } \\
\text { Current }\end{array}$ & $\begin{array}{l}\text { Pulse } \\
\text { length }\end{array}$ & $\begin{array}{l}\text { Rep. } \\
\text { rate }\end{array}$ & Issues/comments \\
\hline $\begin{array}{l}\text { Spallation n- } \\
\text { source/ } p^{+} \text {ind. } \\
\text { linac }\end{array}$ & $1 \mathrm{GeV}$ & $\begin{array}{l}60-100 \\
\text { A }\end{array}$ & $\begin{array}{l}1600- \\
160 \mathrm{~ns}\end{array}$ & $50 \mathrm{~Hz}$ & $\begin{array}{l}\text { Will be easier to sell if } \\
\text { induction technology } \\
\text { more widespread }\end{array}$ \\
\hline $\begin{array}{l}\text { Radiography/ } \\
\text { e- ind. linac }\end{array}$ & $18.4 \mathrm{MeV}$ & $2-4 \mathrm{kA}$ & $\sim 50 \mathrm{~ns}$ & $\begin{array}{l}\sim 2 \mathrm{MHz} \\
\text { bursts of } \\
\text { pulses }\end{array}$ & $\begin{array}{l}\text { DARHT-Il built and } \\
\text { undergoing testing. } \\
\text { lon-hose, beam-target } \\
\text { interactions } \\
\text { AHF to use } \\
\text { protons/synch. }\end{array}$ \\
\hline $\begin{array}{l}\text { Sub-critical } \\
\text { reactor/ ind. FFAG; } \\
\text { H- driver for } \\
\text { spallation n- } \\
\text { source; Accel. } \\
\text { Trans. Waste (H- } \\
\text { ind. FFAG) }\end{array}$ & $1-3 \mathrm{GeV}$ & $\begin{array}{l}10 \mathrm{~mA} \\
(\mathrm{avg})\end{array}$ & $100 \mathrm{~ns}$ & $1 \mathrm{kHz} \mathrm{CW}$ & $\begin{array}{l}\text { May combine rf + } \\
\text { ind.(Ind barrier only); } \\
\text { cost/MW beam power } \\
\text { is low rel. to rf linac; } \\
\text { early design, at idea } \\
\text { stage }\end{array}$ \\
\hline $\begin{array}{l}\text { Driver for } \\
\text { Microwave source } \\
\text { FEL's, BWO }\end{array}$ & MeV & $\sim \mathrm{kA}$ & $\sim \mathrm{few}$ & $\sim \mathrm{kHz}$ & Very attractive match \\
\hline
\end{tabular}

http://nonneutral.pppl.gov/HIF04/US-Japan/02.Barnard.pdf i.e.

- fusion field,

- synchrotron with induction cell

(superbunch, barrier bucket, Fixed-Field Alternating-Gradient)

- high-gradient accelerator (TBA-like)

- spallation neutron and neutrino factory projects

- induction-linac-driven free electron lasers, relativistic rf-sources

The SLIM $\odot$

can be well

suited for

these

programs!

- etc. 


\section{Conclusion}

An induction linac cell for a high gradient is discussed. The proposed solid state coreless approach for the induction linac topology $\left(\mathrm{SLIM}^{\odot}\right)$ is based on nanosecond mode operation. This mode may have an acceleration gradient comparable with gradients of rf- accelerator structures. The discussed induction system has the high electric efficiency. The key elements are a solid state semiconductor switch and a high electric density dielectric with a thin section length. The energy in the induction system is storied in the magnetic field. The nanosecond current break-up produces the high voltage. The induced voltage is used for acceleration. This manner of an operation allows the use of low voltage elements in the booster part and achieves a high accelerating gradient. The proposed topology was tested in POP (proof of principle) experiments. 